\section{A MAGÁNFINANSZÍROZÁS HELYE A MAGYAR EGÉSZSÉGÜGYBEN; FORRÁSHIÁNYBAN AZ EGÉSZSÉGÜGY - MIT TEHETNEK A BIZTOSÍTÓK?}

Prof. Gulácsi László (tanszékvezetö egyetemi tanár, Egészségügyi Közgazdaságtan Tanszék, Budapesti Corvinus Egyetem)

\section{ÖSSZEFOGLALÓ}

Jelen cikk a Portfolio Biztosítás 2016. március 1-jén megtartott konferencia panelbeszélgetése nyomán készült, melynek résztvevői a magyar egészségügyi rendszer jelenlegi helyzetét vitatták meg részletes módon. A beszélgetés azokra a kihívásokra koncentrált, melyekkel a magán-egészségügyi szolgáltatók és a biztosítótársaságok szembesülnek a kérdés kapcsán.

\section{SUMMARY}

The recent article is based on the round table discussion which was held on Portfolio Insurance 2016 Conference on 1st of March. Participants thoroughly discussed the present situation of the Hungarian health care system. The exchange of view focused on challenges that private health care providers and private insurance companies face.

Kulcsszavak: Egészségbiztosítás, magánegészségügy, minőség, költség, Magyarország Keywords: Health insurance, private health care, quality of health care, cost of health care, Hungary

JEL: I11

DOI: $10.18530 / \mathrm{BK} .2016 .2 .88$

http://dx.doi.org/1018530/BK.2016.2.88
A magánfinanszírozás, magánegészségügy egyre nagyobb súllyal van jelen a hazai egészségügyben. Ma már inkább az a megfelelő kérdés, hogy: Mi az állami finanszírozás helye a hazai egészségügyben? A magánszolgáltatók, a magánbiztosítók és az állami egészségügy, egészségpolitika, finanszírozás oldalán jelentős mennyiségű tapasztalat halmozódott fel, az állami-magán együttműködéssel kapcsolatosan. A további fejlődésnek, több más tényező (jogilag szabályozott tiszta keretrendszer fejletlensége) mellett, az adatok hiánya szab gátat. Minőségre és költségekre vonatkozó adatok nélkül egy szolgáltató szektor megfelelő működése/müködtetése elképzelhetetlen.

A magánszféra és az állami pozitívan és negatívan hathat egymásra, és egymás lehetőségeit egyértelműen behatárolják. Az állami-magán szembeállítás kontraproduktív, ezek az ellátási formák akkor tudnak magas színvonalon és hatékonyan müködni, ha ezek egységes rendszert képeznek.

Ezt a kérdéskört vitatta meg a Portfólio Biztosítás 2016 konferencia panelbeszélgetése, március 1-jén a Budavári Hiltonban. A beszélgetés résztvevői voltak: Bóna Katalin, életbiztosítási ügyvezető igazgató, Union Biztosító; Lantos Gabriella, operatív igazgató, igazgatósági tag, Róbert Károly Magánkórház; Zahal Levy, elnök, MediHelp International, Dr. Schiszler István, igazgató, Duna Medical Center Szakrendelő és Sebészeti Központ és Vadas-Földvári Anett, az igazgatóság elnöke, Vienna Life Biztosító.

\section{Elözmények}

Ezzel a kiemelten fontos témával többen foglalkoztak az elmúlt években (Kovács és mtsai. 2015). Egy hosszabb összefoglaló anyagot magunk is közöltünk a Biztosítási Szemlében korábban (Gulácsi és mtsai., 2013), melynek legfontosabb megállapításai a következők voltak:

a) A hazai kutatások szerint a lakosság hajlandó és képes is fizetni egy jelenleginél jobb minőségű egészségügyi ellátásért, és ez az összeg elegendő egy magán-egészségügyi biztosítást is magában foglaló rendszer gyorsabb fejlődéséhez.

b) A magánszolgáltatók és a biztosítók kapcsolata már most is kiterjedt, a további fejlődés érdekében azonban további alapozó munkára van szükség. Válaszolni kell azokra a kérdésekre, hogy ki (lakosság, egészségügyi szolgáltató, biztosító) és mit vár el egymástól, milyen minőségben, áron és szerződéses feltételek mellett.

c) Az egészségügyi ellátás minősége hazánkban mind azállami, mind a magán szektorban ismeretlen, ezt sem szakmai, sem állami szervezet nem ellenőrzi.

d) A társadalombiztosítás által finanszírozott, „alap ellátási csomag "'-hoz való viszony tisztázása megkerülhetetlennek látszik. Az öngondoskodás megköveteli azt, hogy a lakosság tudja, mely területeken „öngondoskodjon” magáról és családtagjairól. Az a szolgáltatás, amelyet a lakosság hálapénz ellenében vehet igénybe, nem része az „alap ellátási csomagnak”.

e) Egyetértés van abban, hogy a demográfiai változások, a lakosság elöregedése miatt az ápolásbiztosítás valószínűleg a magánszolgáltatás, magánbiztosítás egyik legfontosabb területe lesz hosszútávon. Ennek alapja és keretei azonban egyelőre nem tisztázottak. 
Felvetettük, hogy az egyre szükülő állami egészségügyi finanszírozás mellett hazánkban, ahol a lakosság egészségügyi magánfinanszírozása eléri a 35,4 százalékot (OECD)², négy lehetséges kimenet van:

- a lakosság egy részének részleges vagy teljes kizárása a társadalombiztosítás által finanszírozott egészségügyből,

- a magánszolgáltatás, magánbiztosítás valamilyen rendszerének nagyobb térnyerése,

- az „alapellátási csomag” szúkítése,

- a minőség romlása (Gulácsi és mtsai., 2013)

\section{A lakosság hajlandó és képes fizetni egy jelenleginél}

jobb minőségü egészséguigyi ellátásért.

\section{A panelbeszélgetés céljai és a jelenlegi helyzet}

Ennek a rövid, egy óra időtartamú panelbeszélgetésnek a célja az volt, hogy megvizsgáljuk, van-e hazánkban jelenleg igény a magánfinanszírozás, magánbiztosítás további fejlődésére, milyen dinamikájú lehet ez a fejlődés, és az ebben érintetteknek, a biztositóknak és szolgáltatóknak milyen céljaik vannak, céljaik elérése érdekében mit várnak egymástól.

A következőkben a beszélgetésben elhangzottakat foglaljuk össze. Felhívjuk a figyelmet arra, hogy panel résztvevői és a hozzászólók száma limitált, a minta nem reprezentatív. Azonban ezek a vélemények más konferenciákon már nagyon hasonlóan elhangzottak, ezért úgy gondoljuk, hogy a legfontosabb megállapítások, legalább hipotézisek szintjén megfogalmazhatók.

A beszélgetés első részében elmondottakból kiderült, hogy a magánszolgáltatók által ellátott betegek száma az elmúlt években jelentősen nőtt, évente két számjegyű növekedést mutatott. Ennek oka a szolgáltatók véleménye szerint a jobb minőségü, várólista- és várakozásmentes ellátás és a jobb beteginfomáció. A szolgáltatók úgy vélik, ez a tendencia a következő években is folytatódni fog.

A biztosítók helyzetértékelése azt mutatja, hogy több száz, kiváló minőségű szolgáltatóval vannak szerződéses kapcsolatban, és az országos lefedettség is megoldott. Ugyanakkor a néhány évvel ezelőtt $400 \mathrm{md}$ Ft. potenciálra becsült (Portfólio Biztosítási Konferencia 2012) egészségbiztosítási piac 2015-ös nagysága 33600 betegbiztosítási szerződés (2014-ben 32 700) díjbevétele 13,9 Mrd Ft (2014-ben 11,9 Mrd Ft), amely a néhány évvel ezelőtti várakozásoktól jelentősen elmarad (Lenkei 2016). Az elmúlt években a magán-egészségügyi szolgáltató szektor növekedése dinamikusabb volt, mint a releváns biztosítási termékeké.

Az elmondottak alapján úgy tűnik, hogy habár a biztosítók a szolgáltatókkal (illetve szolgáltatás szervezővel) szerződéses kapcsolatban vannak, mélyebb szakmai kapcsolat illetve együttmüködés nincs közöttük

Ennek több oka is valószínűsíthető. Az egyik az, hogy Magyarországon 2012. január 1. előtt ${ }^{3}$ a magán-egészségbiztosítási piac gyakorlatilag összegbiztosításokra korlátozódott. Azaz egy előre meghatározott káresemény (keresőképtelen állományba kerülés, műtéti beavatkozás, maradandó egészségkárosodás) bekövetkezése esetén fix, elöre rögzített összeget fizet a biztosító. Ennél a biztosítási típusnál a térités nagysága közvetlenül nem függ össze az adott betegség ellátásának költségével. A biztosító a biztosítottnak fizet, aki a kapott összeget kötöttségek nélkül szabadon elköltheti. Ezeket az összegbiztosítási konstrukciókat nem tekintik ,igazi” egészségbiztosításnak, szemben az egészségügyi ellátás költségeit részben vagy egészben fedező „valódi” egészségbiztosításokkal (szolgáltatásfinanszírozó egészségbiztosítás). Ez az összegbiztosítás, amelynek arányára a 13,9 Mrd Ft. díjbevételen belül nem találtunk információt, nem igényel biztosító-szolgáltató együttműködést.

A másik az, hogy az egészségbiztosítási szerződést akkor lehet megkötni, ha az ügyfél egészséges, és vállalkozik arra, hogy hosszú időn keresztül fizet átalánydíjat esetleg káresemény nélkül. Ez komoly egyéni elörelátást feltételez, amennyiben a csatlakozás önkéntes . Ettől jelentősen eltérő a másik, a „kötelezően” magánbiztosított biztosítotti csoport, akik számára a munkaadó vásárolt biztosítást. Az egyes biztosítók esetén ennek a 2 csoportnak az aránya nem ismert, feltételezzük, hogy nagyjából 50-50 százalék. A 19-65 éves korúak számára igénybe vehető biztosítottak kormegoszlása azt mutatja, hogy nagy részük 30-49 éves. A biztosítás a járóbeteg-ellátás, a diagnosztika és a laboratóriumi vizsgálatok területén nyújt szolgáltatásokat, amelyek esetén az önkéntes csoportba tartozók kárgyakorisága 50100 százalékkal meghaladja a „kötelező” csoportét (Hevesi, 2015). A szerződés megkötésekor ismert betegséggel nem rendelkező, 30-49 éves, feltehetően a társadalmi átlaghoz viszonyítva jobb anyagiakkal és iskolázottsággal rendelkezö biztosítotti kör, köztük is különösen azok, akik kötelezően biztosítottak, egészségügyi ellátásának költsége nem különösebben jelentős (mondjuk az idősebb, krónikus betegek fekvőbeteg-ellátásához viszonyítva).

\section{Nem tisztázottak a magánbiztosítói - állami fekvőbeteg-ellátó} egyuiittmüködésének a lehetőségei.

Ezzel szemben az egészségügyi szolgáltatóhoz akkor fordulnak a betegek, amikor szükség van rá, és olyan mértékben veszik igénybe, amennyire azt orvosaik szükségesnek látják. A magánellátás is jellemzően járóbeteg-ellátást kínál, amit az előzőekben is leírtaknak megfelelően nem túl gyakran és nem túlságosan nagy összegben vesznek igénybe az emberek. Érdekes kérdés ezzel kapcsolatosan az is, hogy ezeknek a magánszolgáltatásoknak az igénybevétele tehermentesíti-e az állami egészségügyet, vagy esetleg a diagnosztika, szűrés és laboratóriumi vizsgálatok elvégzése megnöveli-e az állami egészségügy költségeit.

Amennyiben a biztosító az ügyfél igényét minél szélesebb palettán igyekszik kielégíteni, akkor ehhez hozzátartozik a fekvőbeteg-ellátás is, amelynek túlnyomórészét jelenleg az állami infrastruktúra kínálja. Ezen a területen azonban nem tisztázottak a magánbiztosítói-állami fekvőbeteg-ellátó együttműködésének a lehetőségei. A magánszolgáltatók ezen a területen korlátozott kapacitást kínálnak a magas belépési korlát miatt. Ezért a már meglévő magán- 
szolgáltatók nagyobbrészt járóbeteg-ellátók, és egynapos beavatkozást ${ }^{5}$ végeznek. A fekvőbeteg-ellátás területéről a biztosítók számára hiányoznak a megfelelő statisztikák (esetszám, demográfiai jellemzők, beavatkozások, kimenet és költség), a biztosítók ezek nélkül nehezen tudnak ellátást rászervezni.

\section{Biztosítók és egészségügyi szolgáltatók; ki fontos kinek és mennyire?}

A panel résztvevői egy képzeletbeli 1-től 10-ig terjedő skálán jelölték meg azt az értéket, hogy napjainkban mennyire fontos számukra a másik féllel való együttműködés (a skálán a 0 az egyáltalán nem fontos, a 10-es a nagyon fontos érték). A biztosítók az egészségügyi szolgáltatókkal való együttmüködés fontosságát ezen a skálán 8-9-es értéküre becsülték, míg a szolgáltatók számára a biztosítók fontossága valahol a 0-1 érték körül mozog. A résztvevők száma kicsi, de mivel a különbség nagyon nagy, és korábban hasonló környezetben adott válaszoknak is megfelel, ezért hipotézisként feltételezhetjük, hogy a szolgáltatók és a biztosítók nagyon eltérően ítélik meg azt, hogy számukra mennyire fontos a másik fél.

A magánszolgáltatók szolgáltatásait igénybe vevők nagyobb része nem rendelkezik magánbiztosítással.

Ebből talán arra lehet következtetni, hogy az egészségügyben egy éretlen magánfinanszírozási, magánbiztosítási piacról beszélhetünk, abban azértelemben, hogy a biztosítás létéből származó előnyök (például kockázatmegosztás) jelenleg korlátozottan érvényesülnek ${ }^{6}$. A beszélgetés során elhangzott, hogy a magánszolgáltatók szolgáltatásait igénybe vevők nagyobb része nem rendelkezik magánbiztosítással, a költségeket egészségpénztáron keresztül térítik, vagy saját maguk fizetik. Ezeket a költségeket a járóbeteg- és egynapos ellátások esetén a lakosság egy része meg tudja fizetni. A fekvőbeteg-ellátás esetén aligha megkerülhető a biztosítók oldaláról az állami infrastruktúra elérése és valamiféle költségmegosztás az állami egészségüggyel.

\section{Milyen ellátást biztosít a magánszolgáltató, miben jobb? És ez honnan tudható?}

Érdekes és a jövőbeni folyamatokra hatással levő kérdés, hogy milyen szolgáltatásokat nyújt a magánszolgáltató. Erről megoszlanak a vélemények, kutatási eredményekkel pedig nem rendelkezünk.

Egyes vélemények szerint a magánszolgáltató a járóbeteg- és egynapos ellátás területén nagyjából ugyanazon egészségügyi ellátásokat biztosítja, mint az állami finanszírozású egészségügy, de ezt kiszámíthatóan, várólista nélkül, kellemes környezetben, jobb minőségben teszi. Emellett a betegek részletes tájékoztatást kapnak a beavatkozásokról és azok várható kimeneteléről, a gyógyulás folyamatáról és az esetleges nemkívánatos mellékhatásokról.

Más vélemények szerint a magánegészségügy, köszönhetően a modernebb technológiajának, jobb és költségesebb műszerparkjának és jobb szakembereinek, olyan ellátásokat, beavatkozásokat nyújt, amelyekre az állami finanszírozású egészségügy nem képes. A betegek tájékoztatását ebben az esetben is fontos szempontként említették a magánszolgáltatók.

$\mathrm{Az}$, hogy melyik állítás a jellemző/igaz, illetve ezek az egyes konkrét ellátási területeken milyen arányban vannak jelen, több szempontból is fontos. Tekintsük át röviden a következő két területet: a minőséget és a költséget.

\section{Minőség}

A biztosítók számos magánszolgáltatóval állnak kapcsolatban, amelyeknek a kiválasztása során fontos szempontnak tartják a szolgáltatások minőségét. Arról azonban, hogy ez a gyakorlatban hogyan valósul meg, nem rendelkezünk információval.

Feltételezhetnénk, hogy abban az esetben, amikor a magánszolgáltató nagyjából azonos szolgáltatást nyújt, mint az állami, csakössze kell hasonlítani az állami és a magánegészségügy minőségi indikátorait ${ }^{7}$ (a betegek gyógyulása, életminősége, munkaképesség visszaszerzése, túlélési arányok, betegbiztonság, kórházi fertőzések), és eldönthető, hogy ki a jobb. Mivel azonban a hazai állami finanszírozású egészségügy minőségéről igen keveset tudunk, ezt az összehasonlítást nem tudjuk elvégezni. A magánszolgáltató megteheti, hogy az adott szakma nemzetközi adataihoz ${ }^{8}$ hasonlítja saját minőségi szintjét. Ez megfelelő menedzsment elkötelezettséggel, szakértelemmel és megfelelő források rendelkezésre állása esetén megvalósítható. A minőség és biztonság garantálása lényeges része lehet a biztosítóval kötött szerződésnek.

Amennyiben a magánegészségügy olyan szolgáltatásokat nyújt, amelyekre az állami finanszírozású egészségügy valamilyen okból nem képes, akkor csak a nemzetközi összehasonlítás a járható út ${ }^{9}$. Ebben az esetben keresni kell olyan standardizált összehasonlítási lehetőséget, ahol azonos/hasonló jellemzőkkel (életkor, nem, betegség súlyossága) leírható betegek, hasonló irányelvek és finanszírozás által meghatározott környezetben részesülnek azonos/hasonló ellátásban. Szakmailag ez is megvalósítható, viszont hazai normák hiányában érdekes kérdések merülnek fel a magánszektor állami szabályozásával, a szolgáltatások garanciális kötelezettségeivel és az esetleges jogi folyamatokkal kapcsolatosan. (A szolgáltatásminőségről alkotott véleményünk lényegében attól függ, mely szolgáltató, milyen betegcsoporttal elért minőségéhez hasonlítjuk magunkat, és milyen módszertant alkalmazunk.)

\section{A minőség garantálása lényeges része a biztosítóval kötött} szerződésnek.

Példa minőségre: egészségügyi ellátással összefüggő fertőzések

A következő példa azt mutatja, hogy miként kapcsolódnak az üzleti biztosítókés magánszolgáltatók a minőségjavulás lehetőségéhez, szükségességéhez. Mivel kórházi ellátás hazánkban túlnyomórészt társadalombiztosítási finanszírozással vehető igénybe, így a minőséggel kapcsolatos problémák elsősorban az állami szektor problémái. Látszólag. Amennyiben azonban 
a biztosítók és a magánszolgáltatók a fekvőbeteg-ellátás területén is szerződnek, alapvetően társadalombiztosítási finanszírozásban részesülő partnerekkel, abban a pillanatban a minőségi kérdések, az ezzel kapcsolatos költségek és garanciális kötelezettségek valamennyi felet érintik. Eza közösérdek, a magánellátás feltehetően magasabb elvárásai pozitív hatást gyakorolhatnak az állami szektor minőségére is.

Azt, hogy milyen jellegű szakmai kérdésekkel kell szembenéznünk, napjainkban (2016. április) a sajtóban gyakran szereplő példán, az egészségügyi ellátással összefüggő fertőzések (Healthcare-associated Infections - HAI) példáján mutatjuk be röviden. Korábban nevezték ezt nozokómiális fertőzésnek, kórházi fertőzésnek is, napjainkban az elterjedt az „egészségügyi ellátással összefüggő fertőzések” kifejezés (továbbiakban HAI). A HAI az egészségügyi ellátással kapcsolatosan jelentkezik, és kialakulásának rizikója külső és belső tényezőktől függ. A külső, betegtől független tényezők közé tartozik például, hogy milyen beavatkozásra van szükség, kell-e katéter, lélegeztetés és ha igen milyen hosszan, milyen típusú a mütéti beavatkozás (aszeptikus környezettől az igen, szeptikus környezetig), milyen hosszú a mütéti beavatkozás. Minél hosszabb egy műtét vagy lélegeztetés, annál nagyobb az esély, hogy a betegnek véráramfertőzése vagy tüdőgyulladása alakul ki. A különböző beavatkozások hossza orvosi szempontoktól, az ápolástól és a menedzsment megfelelöségétől függ. Nagy fertőzési rizikó különbséget okoz például, hogy egy műtét tervezett volt-e, vagy sem.

A belső, betegtől függő tényezők például a beteg kora és betegségének előzményei. Azonos osztályon, azonos sebészeti csoport által elvégzett mütét esetén például jelentősen különböző fertőzési rizikóval kell szembenéznie egy 18 éves olimpikonnak, és mondjuk a 80 éves, évtizedek óta cukorbeteg, magasvérnyomásos, jelentősen túlsúlyos nagymamájának.

\section{A fejlett országokban szokásosan rendelkezésre álló adatokkal} nem rendelkezünk.

Van tehát egy betegtől, beavatkozástól, ellátóhelytől függő rizikó (és konkrét fertőzési előfordulási arány), amely az orvostudomány/egészségügy adott fejlettségi szintjén várhatóan bekövetkezik. Eza fertőzési arány annál magasabb, minél intenzívebb ellátást nyújt egy kórház/ osztály, azaz minél súlyosabbak az ott kezelt betegek. Ezek a betegek sok esetben éppen azért fertőződhetnek meg, mert a fejlett technológia eredményeképpen túlélik azt a súlyos állapotot, amelybe egy-két évtizede még belehaltak volna. A technológia fejlődése tehát egyrészt lehetőséget ad a fertőzések számának kontrollálására, másrészt növeli annak rizikóját. Nem lehet megmondani elöre, hogy a két hatás eredményeképpen egy adott egészségügyi szolgáltatónál, például kórházban, csökken vagy nő a fertőzések, ezen belül a súlyos fertőzések száma. Ezt standardizált definíciók alapján gyüitött adatok összehasonlításával lehet és kell vizsgálni. Erre azért van szükség, mert a HAI definíciója eltér a szokásos orvosi definíciótól, hiszen itt az időtáv is szerepet játszik. Másrészt például a fertőzési arányokat közölhetjük kórházi felvételre, betegre, 1000 ápolási napra vetítve, vagy másképp. Azt hogy egy adott kórházban a fertőzések aránya kiváló vagy nagyon rossz, csak a hasonló hazai és nemzetközi ellátóhelyekkel való összehasonlítás alapján lehet megmondani, standardizált, rizikót is figyelembe vevő adatok segítségével - másképp nem. Hazánkban ilyen összehasonlítást és minőségi fejlesztést célzó standardizált adatgyüjtés nem folyik. Ezt jól példázza az egyik veszélyes kórokozó, a Clostridium difficile-fertőzések előfordulása, amelyről szintén nem rendelkezünk hazánkban megfelelő adatokkal (Gulácsi és mtsai., 2013).

Az egészségügyi ellátással összefüggő fertőzések és a beteginformáció is érdekes kérdéseket vet fel. Mely adatok és mikor álljanak rendelkezésre, és kinek? A gyüjtött adatok vagy a rizikót figyelembe vevő összehasonlítást lehetővé tevő adatok, és mikor? A fejlett országokban szokásosan rendelkezésre álló adatokkal pedig nem rendelkezünk.

A jelenleg rendelkezésre álló adatok (nem nagyon vannak ilyenek), az infekciókontroll szakemberek számára is nehezen vagy sehogyan sem értelmezhetők. Tehát nem az a gond, hogy az adatok titkosak vagy sem, hanem az, hogy a megfelelő adatok hiányoznak. Hazánkban 2015. januártól az OSZIR (Országos Szakmai Információs Rendszer) rendszerében folyik az adatgyüités. Az OEK (Országos Epidemiológiai Központ) begyüjti az adatokat, és összesített adatokat publikál az Epiinfo című lapba. Ezzel több probléma is van. Az egyik az, hogy a gyűjtött adatok minőségét, validitását nem ellenőrzik, és a feldolgozás módszertana sem ismert. A másik az, hogy ebből az egészségügyi intézmények semmit nem tudnak meg a saját infekcióhelyzetükről, ha ezt meg akarják ismerni, akkor helyi adatgyüjtési rendszereket működtetnek (esetleg ahányan annyifélét), pedig ennek a munkának a lényege az összehasonlíthatóság. Ezen a fejlődési fázison - titkos vagy nem titkos az adat?, milyen információ álljon rendelkezésre a szolgáltatóról (és biztosítóról!)?, kinek, milyen formában és mikor? - a fejlett országok is keresztülmentek a 90-es években. Ezeknek a vitáknak mindenütt az lett a vége, hogy az adatokat hozzáférhetővé kellett tenni (nagyok az országok közötti különbségek).

Úgy tủnik, a szakmai szervezetek információigénye és a biztosítók és a szolgáltatók jobb együttmüködésének az igénye talán abba az irányba hat, hogy ezek az egyeztetések és a szakmai munka megkezdődhessen hazánkban is.

\section{Költség, finanszírozás}

A költség- és szektorsemleges finanszírozás kérdésének szempontjából jó példa az állami és a magánszektor által is végzett egynapos sebészet, amelynek több előnye is lehet. Az egynapos sebészet potenciálisan kevésbé költséges és gyorsabb az alacsony rizikójú beavatkozások esetén. A betegek és egészségügyi szakemberek számára jobb helyeken (megközelíthetőség) biztosítható, nincs éjszakázás/hétvége (a megfelelő munkaerő biztosítása elsődleges szemponttá vált). Az ellátó kevés fajta beavatkozást végez, emiatt jobb lehet a minőség, és alacsonyabb a költség, mint a kórházakban, ahol nagyszámú különböző beavatkozást végeznek. A fontos kérdés ezzel kapcsolatosan az, hogy különböző-e az egynapos ellátás és a kórházi ellátás (azonos/hasonló beavatkozások) betegösszetétele (patient mix)? Függ-e/függiön-e a finanszírozás attól, hogy milyen a betegek egészségi állapota? Az egynapos ellátás profitabilitásnövelésének az egyik módja, ha növelik a relatíve egészségesebb betegek arányát, akiknek a kezelése is olcsóbb. Ez 
problémát jelenthet azonban a finanszírozás során a szolgáltatások árának/térítési összegének meghatározása szempontjából. Kérdés az, hogy egy esetleges társadalombiztosítási szerződés esetén az egynapos magánellátó és az állami finanszírozású kórház azonos vagy különböző finanszírozásban részesüljön-e, azaz a szektorsemleges finanszírozás azonos összeget jelent-e, vagy azonos finanszírozási módszertant.

A betegek egészségi állapota erős prediktora a műtéti beavatkozás típusának, a beavatkozás hosszának és a posztoperatív ellátásnak, azaz a kimenetnek és a költségeknek.

Sokat segítene, ha hazánkban is jobban ismernénk az egészségnyereséget.

Felmerül a kérdés, hogy az egynapos ellátás jobb minőségű-e, mint a kórházi? A nagyobb esetszám és specializáció miatt ennek megvan a lehetősége. A lehetősége van meg, de nem a garanciája, az eredményt vizsgálni kell. Azonos beavatkozás a rizikótól függően végezhető egynapos és kórházi ellátás keretében. A költségek várhatóan különbözők. A magasabb rizikójú betegek esetén valószínű, hogy a kórház a jobb választás (jobb a felszerelés ehhez a betegcsoporthoz, több szakember). A kérdés, hogy hol van ez a rizikóhatár, ezt csak adatok alapján lehet megmondani, és valószínűleg országfüggő.

Összefoglalva elmondható, hogy az egynapos sebészet potenciálisan olcsóbb, gyorsabb, jobb minőségü, a betegeknek és az egészségügyi szakembereknek is vonzóbb. Ezt elég jó minőségü szakirodalom igazolja. Sokat segítene, ha hazánkban is jobban ismernénk az egészségnyereséget, a minőséget és a költségeket a különböző ellátási formák esetén.

\section{Összefoglalás}

A magánfinanszírozás, magánegészségügy egyre nagyobb súllyal van jelen a hazai egészségügyben. Ma már inkább az a megfelelő kérdés, hogy: mi az állami finanszírozás helye a hazai egészségügyben?

A magánszolgáltatók, a magánbiztosítók és az állami egészségügy, egészségpolitika, finanszírozás oldalán jelentős mennyiségü tapasztalat halmozódott fel, az állami-magán együttmüködéssel kapcsolatosan. A további fejlödésnek több más tényező (jogilag szabályozott tiszta keretrendszer fejletlensége) mellett, az adatok hiánya szab gátat. Minőségre és költségekre vonatkozó adatok nélkül egy szolgáltató szektor megfelelő működése/működtetése elképzelhetetlen.

A magán és azállami szektor nagyon összefügg egymással. Itt nem csak arra gondolunk, hogy a gyógyszereket például mindkét ellátásban a társadalombiztosítás finanszírozza, a költséges laboratóriumi, szövettani vizsgálatok és beavatkozások állami finanszírozással, állami intézményekben történnek. És nem is arra, hogy magánszolgáltatóval köt szerződést a társadalombiztosítás. Párhuzamos kapacitások kialakítása és föleg a fenntartása nagyon sokba kerülne. Az egészségügy nagyon bonyolult rendszer. Ez nem a verseny által vezérelt szabad piac, ahol a kereslet és a kínálat kisebb-nagyobb döccenőkkel, állami beavatkozásokkal ugyan, de időről időre egyensúlyban van. Az egészségügy alapvetően állami feladat ${ }^{10}$, és az európai öregedő társadalmak jelenlegi és jövőbeni forrásigényét elnézve az is marad. Sőt, az állam (finanszírozó, szabályozó) szerepe, úgy tűnik, egyre nő.

A magán- és állami szféra pozitívan (és negatívan) hathat egymásra, de egymás lehetőségeit egyértelmüen behatárolják. Az állami-magán szembeállítás kontraproduktív, ezek az ellátási formák akkor tudnak magas színvonalon és hatékonyan müködni, ha egységes rendszert képeznek.

\section{IRODALOMJEGYZÉK}

Baji P. - Pavlova M. - Gulácsi L.: Groot W. Does the Implementation of Official User Charges Help to Eradicate Informal Payments

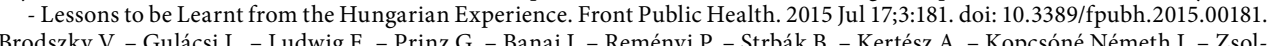
diné Urban E. - Baji P. - Péntek M. A Clostridium difficile-fertỏzések antibiotikum-terápiája: A tudományos bizonyitékok szisztematikus átekintése és metaanalízise. ORVOSI HETILAP, 154(23): pp. 890 - 899. (2013)

Gulácsi L. - Baji P. - Kovács E. - Farkas R. - Leitner Gy. - Gamal EM. - Simon T. - Balogh O. - Boncz I.: Magánpraxis, egészségbiztositás, szerződés és biztonság. Biztositási Szzemle, 2013:(febr. 14.) pp. 1 - 29. (2013)

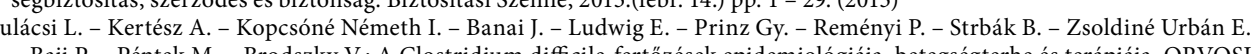

2012-2014. Budapesti Corvinus Egyetem, Közgazdaságtudományi Kar Egészség-gazdaságtani és egészségbiztositási szakközgazdász szak, 2015 (Konzulens: Dr. Baji Petra)

Lenkei G.: Kárverseny, HVG, 2016. április 9. p.: p. 44

Gesi L : Quality management and patient safety: Survey results from 102

Kovács $\mathrm{E}$ - Kiss $\mathrm{N}$ - Kovíss $\mathrm{E}$ - Tőkey $\mathrm{B}$ · A magán-egészséghiztositás helyzete, szerepe és lehetőségei (Európai kitekintés és magyarországi helyzetkép). BOKCS-MABISZ Kutatás 2014-2015, 2015. Budapest

Portfolio Biztositasi Konferencia 2012, http://www.portfolio.hu/rendezvenyek/portfoliohu_biztositasi_konferencia_2012/118/

\section{HIVATKOZÁSOK}

'Az, „alapellátási csomag” azon egészségügyi ellátások összessége, azok számszerüsége, minősége és költsége (teljesen finanszírozott vagy beteg hozzájárulással terhelt), amelyre a társadalombiztositott lakosság a tb-befizetések ellenében jogosult.

ö̈zö területeken zsebböl történő (out of pocket) kifizetések 28,3\% volt 2012-ben (Baji és mtsai. 2012). Fel kell hívnunk 作

011. évi CLVI. törvény - megszűnt a nem természetes személyek adó- és járulékfizetési kötelezettsége az általuk kötött egészségbiztositási szerződések díja után.

${ }^{4}$ Ezt a biztositást a biztosítottak jellemzően saját adózott jövedelmükből, illetve valamilyen választható, önkéntes (bérből történő levonás, cafeteria) munkaadói juttatási program keretében ,vásárolják” meg.

${ }^{5}$ Az egynapos sebészeti ellátás 24 óránál rơvidebb ellátási időt igényel.

${ }^{6}$ Az okok között gyakran kerül emlitésre az is, hogy a magánbiztositással rendelkezőknek duplán kell fizetniük (egészségügyi hozzájárulás + magánfinanszírozás), mivel nem megoldott az osztott finanszírozás. Ezzel a kérdéssel, terjedelmi okok miatt, jelen tanulmanyunkban nem foglalkozunk.

OECD Health Care Quality Indicators http://www.oecd.org/els/health-systems/health-care-quality-indicators.htm

${ }^{8}$ például: https://www.hirslanden.ch/global/en/home/about_us/quality/results_measurements/iqip.html és http://www.ahrq.gov/

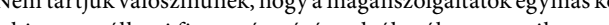
hiszen az állami finansźrozású szolgáltatók sem teszik ezt.

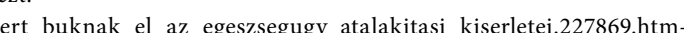

l?utm_sorce=index_main\&utm_medium=portfolio_box\&uknak_el_az_egeszsegugy_ 